\title{
New Trends in Urban Life of Turkey in the Context of Lifestyle Migration
}

\author{
Betül Kızıltepe \\ Balkesir University, Faculty of Science and Literature, Balıkesir, TURKEY \\ Department of Sociology
}

Received: 14 March 2020 • Accepted: 28 May 2020 • Published Online: 20 July 2020

\begin{abstract}
Demographic structures and difficult living conditions of metropolitan cities affect the search for different lifestyles by individuals living in these cities. This presents a different concept: lifestyle migration. In cities, spatial and social transformations, persuade individuals to have a simple life style than those who live in the metropolis. Today, the migration pattern has transformed from large-scale cities to smaller-scale cities. Boredom and the rat race of metropolitan life lead individuals to live in smaller-scale cities instead of large-scale. This study has explored people's migration from İstanbul to provinces during the last three years. Findings suggests that increasingly people select locations to migrate to, considering the effect it will have on their quality of life. This research aims to indicate that urban density and changing urban conditions lead individuals to live in relatively smaller cities and reveal the different trends in urban life in the context of Turkey. In this research, which is based on the secondary data analysis, migration patterns and new urban trends have been determined by examining the intercity migration data of Turkey.
\end{abstract}

Keywords: lifestyle migration, new urban tendency, better life, metropolitan city, smaller-scale city.

\section{Introduction}

Lifestyle migration is a new type of contemporary migration and mobility. It includes domestic and international migrants. These individuals "present migration as a route to a better and more fulfilling way of life. This way of life emphasizes on lifestyle choices specific to individuals of the developed world" (O’Reilly \& Benson, 2009: 1). It is conceptualized as antimodernist (living in the village and staying away from urban lifestyle), escapist (escape from problems), self-realization project or a search for the intangible good life (O'Reilly \& Benson, 2009). But the main motivation is that migrants want to live a better and less stressful life and they migrate primarily to change their life style rather than to pursue their economic goals. Lifestyle migration has different processes, motivations and experiences from other types of migration. Individual motivations underpinning life style migration includes: the fear of ecological catastrophe, the desire to escape to a safe and good place, a new type of life (Nefedova, Pokrovskii \& Treivish, 2016). Besides, countries' economic and social changes are important factor to facilitate the people's lifestyle migration (Hoey, 2010; Torkington, 2012; Eimermann, 2013; Huete, Mantecón \& Estévez, 2013; Gkartzios \& Scott, 2015; Aner, 2016; Robins, 2019).

(C) Authors. Terms and conditions of Creative Commons Attribution 4.0 International (CC BY 4.0) apply. Correspondence: Betül Kızltepe, Balıkesir University, Faculty of Science and Literature, Department of Sociology, Balıkesir, TURKEY. E-mail: betulkiziltepe@balikesir.edu.tr. 
Lifestyle migration is an inclusive concept because it contains different sorts of migrations such as: residential migration, retirement migration, counter-urbanization, second home ownership and seasonal migration (Benson, 2010; O’Reilly \& Benson, 2009; Benson \& O’Reilly, 2009; ÆrØ, 2006; Clark \& Onaka, 1983; Clark, Deurloo \& Dieleman, 1984). The different types of migrations are related to the life choices of migrants who want a better life. From a better life style means, "the (re)negotiation of the work-life balance, the pursuit of a good quality of life, freedom from prior constraints" (O'Reilly \& Benson, 2009: 2). This migration is important for people to make sense of contemporary life practices because the existing types of migration are not enough to interpret this phenomenon so they need new types of migration. In this context, people decide on their life route and it is related to their individual choice and new lifestyle (Tekeli, 2007: 471).

The urban displacement of individuals, from the metropolitan areas to relatively smaller areas, is based on improving their quality of life. In addition to the spatial change of the population, this migration symbolizes a different phase of urbanization. It presents the difference of lifestyle perception and individuals' preferences/ understandings of a new urban life. Life becomes more fluid than in the past by the effect of modernity, and this change also means occurring of the different types of migration. In spite of the increasing population density in largescale cities, new migration movements create new urban life preferences and urban tendencies.

Urban areas have different economic, social and everyday life dynamics from rural areas and these dynamics cover a wide range from the relationships between individuals to spatial change, and from economic developments to demographic change. All of them include different lifestyles, cultural patterns and personality structures (Simmel, 1969: 50-55; Şatıroğlu, 2014: 398). The increasing density in the city causes chaotic structure and affects individuals' daily lives. While the metropolitan city provides the opportunity of autonomy and personality that is not found in rural life, it requires a level of caution and feeling of displacement not experienced in small towns; the fact that the city is sustained solely within the money economy forces the individual to be increasingly punctual, calculating, and exact, all of which characterize city life (Simmel, 1969: 50-51). According to Simmel (1969: 55), the money economy matched with being the main place of boredom, and the intense and compressed life in the city causes the individual to become mentally distant and tired. Lefebvre (1996: 127-8) suggests:

The ordering and arrangement of daily life, the massive use of the car, mobility, and the influence of the mass media have detached from site and territory individuals and groups. Neighborhood and district fade and crumble away: the people move about in a space which tends towards a geometric isotopy.

In modern city life, social activity is carried out by the behavior that is called as tactful indifference. This distance gives individuals the confidence in their daily lives (Goffman, 1956). Thus, it is clearly evident that there is a lifestyle special to the city and individualism is an important value in the city's life and it creates dissociation. Dissociation is only one of the basic forms of socialization in the city and the area of personal freedom risen by the distance shows a "relatively small circle" tendency (Simmel, 1969: 54). The physical intimacy in a crowded and chaotic structure of the city is not sufficient for mental intimacy. The distance increases with the population and spatial density of the cities. Therefore, mental intensity and fatigue in the city give rise to different problems over time.

The population pressure of the cities causes the individual's desire to escape. Escape or migration demonstrates that individuals want to change social, political, economic and hard conditions in the city (Tuan, 2015: 30). In the past, we viewed migration as a symbol of escape from the country to urban. However, now it represents an escape to nature, indicating that the people's preferences vary according to time and condition. Besides, the change in social, environmental and economic conditions has led to an increase of attention to environmental 
movements and environmental culture and the change of ideas and perceptions about the nature (Tuan, 2015: 42). Giddens's structural theory (1986) suggests that the actions of individuals are influenced by changes in the society and thus individuals begin to apply different practices under social conditions (such as lifestyle migration).

The escape from the metropolis can also be defined as a part of the change or selfrealization. The individual, who lives in the metropolis, describes a better place/city/life where she/or he escapes than in the metropolitan city. According to Giddens (1991: 77), time and its emphasis are self-actualization and the flow of daily social life because of "the establishing of zones of personal time which have only remote connections with external temporal orders". As a matter of fact, "holding a dialogue with time is the very basis of self-realization, because it is the essential condition of achieving satisfaction at any given moment - of living life to the full" (Giddens, 1991: 77). Moreover, lifestyle migration includes both opportunities and risks. In the process of selfrealization and adaptation of a new lifestyle, the individual can find what she/or he wants and takes the opportunity while s/he may take the risks such as a new life and adaptation process.

With regard to self-realization, the routine decisions are important because "modernity confronts the individual with a complex diversity of choices and, because it is nonfoundational, at the same time offers little help as to which options should be selected" (Giddens, 1991: 80). In this regard, the importance of lifestyle appears.

Lifestyle implies choice within a plurality of possible options. Lifestyles are routinized practices, the routines incorporated into habits of dress, eating, modes of acting and thus each of the small decisions a person makes every day contributes to such routines" (Giddens, 1991: 81).

Aspects or routine and daily life are characteristics which build the individual's identity and symbolize the individual's lifestyle. They are the individual's life project and show that the individual continues to consume in accordance to their lifestyle.

To sum up, lifestyle migration is a new concept in the literature, it offers a new beginning and life that can be preferred rather than the life before migration and it is defined as an individual decision to realize themselves. The idea of relocation and the preference of a life outside the large-scale city in order to have a better life are becoming widespread all over the world. Migrants explain their movements by comparing disadvantages and inadequacies of their previous locations/residences such as: increased crime rate, unemployment, reduced social spirit, coercive lifestyle, etc.) with features of their current locations/residences (slow pace of life, cheap life, climate and health benefits, community feeling, and so on (Benson \& O'Reilly, 2009). Therefore, the migration stories emphasize the individualized and the self-realizing narrative of the migration decision, and symbolic capital that is combined with education, cultural and social capital influences the decision on migration and the chosen place (Benson \& O'Reilly, 2009: 61016). The escape from the metropolis includes the return to true self and the search for happiness in the context of a better life. The will and choice of individuals leave their marks on lifestyle and the art of life which include having a good life in pursuit of happiness as the prime engine of human thought and action (Bauman, 2008: 53).

In this study, the lifestyle migration has been discussed within the context of Turkey. This study contributes knowledge into the lifestyle migration, which has not been fully explored in Turkey to date. It aims to investigate the migration patterns and trends in urban life. Many people migrate from İstanbul to small-scale cities to have a better life. Middle and old aged people are more likely to migrate to change their lifestyle in Turkey. In this sense, the purpose of this study is to analyze the trends depending on the recent migration patterns in the country. The migration data, between 2013 and 2018 years, have been used and it is aimed to define migration patterns of the city in order to determine the change in the migration structure. The study's second aim is to find out people's preferences about the locations of their migration locations. The change 
in the urban, migration from large-scale cities to the small-scale cities, structure, and trajectory of lifestyle migration has been discussed in study within the concept of Turkey/İstanbul and the demographic data has been interpreted from a sociological perspective.

\section{Research method}

\subsection{Research model}

This study has used secondary data analysis of quantitative data, which provides a picture of the current situation of the population and concrete data makes it easier to monitor the change and transformation in the population. "Secondary analysis involves the re-use of preexisting qualitative and quantitative data derived from previous research studies" (Heaton, 2008: 34). Formal data sharing is the most important mode of quantitative data in secondary data analysis because researchers can access datasets in public or institutional archives and re-use them in secondary research (Heaton, 2008: 35).

\subsection{Data collection tool}

Turkish Statistical Institute's (TurkStat) formal datasets have been used and these are comprised of: results of General Population Censuses, Address Based Population Registration System and Well-being Index in this research. These data are collected periodically, their reports are presented regularly and databases are available in the website.

\subsection{Data analysis}

In this study, data interpretations have been made mainly in the context of migration data and well-being index data, and migration trends have been described. As a matter of fact, the population of countries does not only provide numerical data but also historically, it draws pictures of social changes and transformations. Migration and well-being index data enables to offer interpretations regarding the change of migration pattern in Turkey. Istanbul, Turkey's most crowded city, gives important clues in the context of migration dynamics and new urban trends. The city has a population of 15 million and the city can be considered as a case study to offer significant analysis in the context of Turkey's transformation. The sample of this research consists of migrants from İstanbul to other parts of Turkey. In this study, thus migration from İstanbul to the country's other provinces between 2013 and 2018 has been analyzed. This study has attempted to depict the common characteristics of the province, and it has presented the new urban trends in Turkey.

\section{Results}

In the 1950s, Turkey faced a rapid urbanization process, which resulted in the prominence of İstanbul, Ankara and İzmir as the major metropolitan cities, and marked the transition from a rural Turkey to one based on urban centers. Thusly, a decrease in the rural population and an increase in the urban population facilitated a rise in the urbanization rate. The most important developments took place in İstanbul and the city experienced the most important changes in the urban population. Consequently, İstanbul's urban population is higher than the urban population of Turkey's other cities (Table 1). As per the 2018's statistics, Ístanbul's total population is $15,067,724$ and still the city is the most crowded city in Turkey. 
Table 1. Urban population in Turkey and İstanbul

\begin{tabular}{|lcc|}
\hline Years & $\begin{array}{c}\text { Urban population (\% of } \\
\text { total) in Turkey }\end{array}$ & $\begin{array}{c}\text { Urban population (\% of total) } \\
\text { in Istanbul }\end{array}$ \\
\hline $\mathbf{1 9 2 7}$ & 24.2 & 75.8 \\
\hline $\mathbf{1 9 5 0}$ & 25.0 & 85.9 \\
\hline $\mathbf{1 9 7 0}$ & 38.4 & 73.0 \\
\hline $\mathbf{1 9 9 0}$ & 59.1 & 92.4 \\
\hline $\mathbf{2 0 1 0}$ & 76.3 & 96.4 \\
\hline
\end{tabular}

Source: Table generated using data from the General Population Census and Address Based Registration System in TurkStat.

İstanbul had become a crowded city, when intensive migration from rural areas to urban areas started during the 1950s. However, İstanbul has experienced net out-migration since 2015, as in Table 2. This increased migration rate makes possible to analyze the different urban trend in the context of escape from the metropolis, new mobility and lifestyle changes. Today, the quality of life gradually becomes more difficult in İstanbul because the increasing population brings several problems such as: transportation, environment and security problems. These aforementioned problems affect the quality of life in the city. In this regard, the structures of the cities that receive migration from İstanbul and the new urban tendencies have been examined in the study.

Table 2. İstanbul's migration statistics 1965-2018

\begin{tabular}{|c|c|c|c|c|}
\hline Periods & $\begin{array}{c}\text { Total } \\
\text { population }\end{array}$ & $\begin{array}{l}\text { Migration to } \\
\text { Istanbul }\end{array}$ & $\begin{array}{l}\text { Migration from } \\
\text { Istanbul }\end{array}$ & $\begin{array}{c}\text { Rate of net } \\
\text { migration }(\% o)\end{array}$ \\
\hline $\begin{array}{l}\text { 2017- } \\
2018^{(1)}\end{array}$ & $15,067,724$ & 385,482 & 595,803 & -13.9 \\
\hline $\begin{array}{l}\text { 2016- } \\
2017^{(2)}\end{array}$ & $15,029,231$ & 416,587 & 422,559 & -0.4 \\
\hline $\begin{array}{l}\text { 2015- } \\
\text { 2016(2) }^{(2)}\end{array}$ & $14,804,116$ & 369,582 & 440,889 & -4.8 \\
\hline $\begin{array}{l}\text { 2014- }^{-} \\
\text {2015 }^{(2)}\end{array}$ & $14,657,434$ & 453,407 & 402,864 & 3.5 \\
\hline $\begin{array}{l}2013^{-} \\
2014^{(2)}\end{array}$ & $14,377,018$ & 438,998 & 424,662 & 1.0 \\
\hline $\begin{array}{l}\text { 2012- } \\
\operatorname{2013}^{(2)}\end{array}$ & $14,160,467$ & 437,922 & 371,601 & 4.7 \\
\hline $\begin{array}{l}\text { 2011- } \\
\operatorname{2012}^{(2)}\end{array}$ & $13,854,740$ & 384,535 & 354,074 & 2.2 \\
\hline $\begin{array}{l}\text { 2010- } \\
\operatorname{2011}^{(2)}\end{array}$ & $13,624,240$ & 450,445 & 328,663 & 9.0 \\
\hline $\begin{array}{l}\text { 2009- } \\
\text { 2010(2) }^{(2)}\end{array}$ & $13,255,685$ & 439,515 & 336,932 & 7.8 \\
\hline $\begin{array}{l}\text { 2008- } \\
2009^{(2)}\end{array}$ & $12,915,158$ & 388,467 & 348,986 & 3.1 \\
\hline $\begin{array}{l}2007^{-} \\
2008^{(2)}\end{array}$ & $12,697,164$ & 374,868 & 348,193 & 2.1 \\
\hline $\begin{array}{l}\text { 1995- }^{-} \\
\text {2000 }^{(1)}\end{array}$ & $9,044,859$ & 920,955 & 513,507 & 46.1 \\
\hline $\begin{array}{l}1985^{-} \\
1990^{(1)}\end{array}$ & $6,433,569$ & 995,717 & 339,040 & 107.6 \\
\hline $\begin{array}{l}\text { 1980- } \\
1985^{(1)}\end{array}$ & $5,068,512$ & 576,782 & 279,184 & 60.5 \\
\hline
\end{tabular}


B. Kizlltepe - New Trends in Urban Life of Turkey in the Context of Lifestyle Migration

\begin{tabular}{|lllll|}
\hline $\begin{array}{l}\mathbf{1 9 7 5}^{-} \\
\mathbf{1 9 8 0}^{(1)}\end{array}$ & $4,074,806$ & 557,082 & 268,429 & 73.4 \\
\hline $\begin{array}{l}\mathbf{1 9 7 0}^{-} \\
\mathbf{1 9 7 5}^{(\mathbf{1})}\end{array}$ & $3,904,588$ & 683,540 & 242,298 & 127.5 \\
\hline $\begin{array}{l}\mathbf{1 9 6 5}^{-} \\
\mathbf{1 9 7}^{(\mathbf{1})}\end{array}$ & $3,019,032$ & 714,126 & 163,974 & 207.1 \\
\hline
\end{tabular}

Notes: (1) Foreigners residing within the borders of the country are covered.

(2) Foreigners residing within the borders of the country are not covered.

Source: Table generated using data from the General Population

Census and Address Based Registration System in TurkStat.

According to various studies, the population density of İstanbul affects the characteristics of the city. Today, İstanbul includes a stressful environment, transportation problems and increased level of air pollution and fewer green areas as compared to other metropolitan cities. Hence the urban sprawl of İstanbul consumes not only the city itself, but also surrounding cities. For example, Istanbul's water resources are not enough for the population because of the density and the settlement in water basins (Düzce-Melen, Tekirdağ-Kazandere, Pabuçdere). Also, the negative life conditions depending on the density diminish the city's attraction gradually. In this environment, some of İstanbul's residents tend to migrate back to the town or province from which they originally migrated years ago, while other individuals migrate to a city they perceive as more livable. This indicates that lifestyle migration provides a meaningful description of the migrated population (from İstanbul to other cities), as well as the definition of new mobility.

When İstanbul's migration data for the last five years was examined (see Table 3), the top ten destination provinces were: Kocaeli, Tekirdağ, Ordu, Tokat, Balıkesir, Giresun, Bursa, Sakarya, Sivas, Trabzon, Antalya, Muğla, Samsun, Kastamonu, Çankırı and Rize. The most important qualification of these cities is to have the lowest population density.

Table 3. Migration rate from İstanbul to Turkey's other provinces 2013-2018

\begin{tabular}{|c|c|c|c|c|c|c|c|c|c|}
\hline 2013-2014 & $\%$ & 2014-2015 & $\%$ & $2015-2016$ & $\%$ & 2016-2017 & $\%$ & 2017-2018 & $\%$ \\
\hline KOCAELI & $5 \cdot 50$ & KOCAELI & 7.00 & KOCAELI & 6.70 & KOCAELİ & 6.40 & ORDU & 5.00 \\
\hline TEKİRDAĞ & 5.00 & TEKİRDAĞ & 5.80 & TEKİRDAĞ & 5.80 & TEKİRDAĞ & 5.50 & KOCAELI & 4.30 \\
\hline TOKAT & 4.30 & ANKARA & 4.70 & ORDU & 4.90 & ANKARA & 4.70 & TOKAT & 4.30 \\
\hline ANKARA & 4.20 & İZMİR & 4.00 & ANKARA & $4 \cdot 30$ & İZMİR & 4.40 & TEKİRDAĞ & 3.90 \\
\hline BALIKESİR & 4.10 & TOKAT & 3.80 & GİRESUN & 4.10 & TOKAT & 4.10 & GİRESUN & 3.60 \\
\hline İZMİR & 3.90 & ORDU & 3.20 & İZMİR & 3.90 & BURSA & $3 \cdot 30$ & İZMİR & 3.40 \\
\hline GİRESUN & 3.00 & BURSA & 3.20 & TOKAT & 3.90 & ORDU & 2.80 & ANKARA & 3.40 \\
\hline ORDU & 2.80 & SAKARYA & 3.00 & BURSA & 3.20 & GÍRESUN & 2.80 & SIVAS & 3.10 \\
\hline BURSA & 2.80 & ANTALYA & 2.70 & SAKARYA & 2.70 & SAKARYA & 2.70 & TRABZON & 2.70 \\
\hline MUĞLA & 2.60 & SAMSUN & 2.50 & SAMSUN & 2.50 & ANTALYA & 2.70 & SAMSUN & 2.70 \\
\hline SIVAS & 2.60 & KASTAMONU & 2.40 & ANTALYA & 2.30 & SAMSUN & 2.50 & ÇANKIRI & 2.50 \\
\hline SAKARYA & 2.40 & BALIKESİR & 2.20 & BALIKESİR & 2.10 & BALIKESİR & 2.30 & RİZE & 2.50 \\
\hline
\end{tabular}

Source: Table generated using TurkStat data.

Migration patterns also vary according to age groups. When the age distribution of migrants was examined, it was noticed that the share of the population over 40 years of age in the migration rate had increased over years (as in Table 4). 
Table 4. Age distribution of migrants from İstanbul

\begin{tabular}{|c|c|c|c|c|c|}
\hline & 2013-2014 & 2014-2015 & 2015-2016 & 2016-2017 & $2017-2018$ \\
\hline $0-4$ & $5.5 \%$ & $6.2 \%$ & $6.6 \%$ & $6.6 \%$ & $5.3 \%$ \\
\hline 5-9 & $5.5 \%$ & $6.3 \%$ & $6.7 \%$ & $6.3 \%$ & $5.1 \%$ \\
\hline $\begin{array}{l}10- \\
14\end{array}$ & $4.6 \%$ & $5.1 \%$ & $5 \cdot 3 \%$ & $5.1 \%$ & $4.5 \%$ \\
\hline $\begin{array}{l}15^{-} \\
19\end{array}$ & $10.2 \%$ & $12.2 \%$ & $11.5 \%$ & $10.6 \%$ & $9.0 \%$ \\
\hline $\begin{array}{l}\text { 20- } \\
24\end{array}$ & $13.1 \%$ & $15.1 \%$ & $14.5 \%$ & $15.1 \%$ & $12.5 \%$ \\
\hline $\begin{array}{l}\mathbf{2 5}^{-} \\
\mathbf{2 9}\end{array}$ & $11.1 \%$ & $12.2 \%$ & $11.7 \%$ & $12.2 \%$ & $10.1 \%$ \\
\hline $\begin{array}{l}\text { 30- } \\
34\end{array}$ & $8.6 \%$ & $9.5 \%$ & $9.5 \%$ & $9.5 \%$ & $8.2 \%$ \\
\hline $\begin{array}{l}\text { 35- } \\
39\end{array}$ & $6.0 \%$ & $7.0 \%$ & $7.6 \%$ & $7.6 \%$ & $7.1 \%$ \\
\hline $\begin{array}{l}40- \\
44\end{array}$ & $4.5 \%$ & $5.0 \%$ & $5.3 \%$ & $5.2 \%$ & $5.6 \%$ \\
\hline $\begin{array}{l}45^{-} \\
49\end{array}$ & $3.9 \%$ & $3.9 \%$ & $4.3 \%$ & $4.3 \%$ & $5.4 \%$ \\
\hline $\begin{array}{l}\text { 50- } \\
54\end{array}$ & $5.0 \%$ & $4.7 \%$ & $5.0 \%$ & $4.7 \%$ & $6.2 \%$ \\
\hline $\begin{array}{l}5^{-} \\
59\end{array}$ & $5.7 \%$ & $4.1 \%$ & $4.0 \%$ & $4.3 \%$ & $6.4 \%$ \\
\hline $\begin{array}{l}60- \\
64\end{array}$ & $5.5 \%$ & $3.4 \%$ & $3.4 \%$ & $3.5 \%$ & $5.8 \%$ \\
\hline $65^{+}$ & $10.7 \%$ & $5 \cdot 3 \%$ & $4.6 \%$ & $4.9 \%$ & $8.9 \%$ \\
\hline
\end{tabular}

Source: Table generated using TurkStat data.

Migration from İstanbul, in the last five years, tends to be toward small-size towns and medium-size urban areas. In other words, people escape from large-scale urban areas to lesspopulated areas, including medium-size urban areas (population between 200,000 and 500,000) and small urban areas (population between 50,000 and 200,000). As we can see, most of the provinces where people migrate from İstanbul are smaller-size urban areas (Table 5).

Table 5. Migration from İstanbul to Other Provinces with Population

\begin{tabular}{|lcccccc|}
\hline Province & Ankara & İmmir & Bursa & Antalya & Kocaeli & Samsun \\
\hline Population & $5,503,985$ & $4,320,519$ & $2,994,521$ & $2,426,356$ & $1,906,391$ & $1,335,716$ \\
Province & Balıkesir & Tekirdağ & Sakarya & Mugla & Trabzon & Ordu \\
Population & $1,226,575$ & $1,029,927$ & $1,010,700$ & 967,487 & 807,903 & 771,932 \\
Province & Sivas & Tokat & Kastamonu & Giresun & Rize & Çankurı \\
Population & 646,608 & 612,646 & 383,373 & 453,912 & 348,608 & 216,362 \\
\hline
\end{tabular}

Source: Table generated from Address Based Registration System data in TurkStat.

Most people, who live in Istanbul, are those who were born in Sivas $(364,641)$, Ordu $(293,163)$, Tokat $(289,990)$, Samsun $(279,391)$ and Erzurum $(251,299)$ (TurkStat, 2018). The attraction of these provinces is seen in migrants from İstanbul in the last three years. Moreover, the rest of the provinces can be characterized as smaller cities when they are compared to İstanbul. As reported 2015 well-being index data, it is possible to see the detail of provinces and rankings in terms of different values, and we can notice that İstanbul has the lowest ranking regarding to security, education and life satisfaction (Table 6). At this point, it is seen that people generally migrate to provinces where there is less population; better levels of safety, education and life satisfaction. İstanbul is one good example in this context. 
Table 6. Provinces (receiving migration from İstanbul) and index of well-being, 2015

\begin{tabular}{|c|c|c|c|c|c|c|c|c|c|c|c|}
\hline 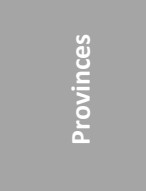 & 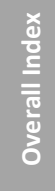 & $\begin{array}{l}\text { 음 } \\
\text { 을 }\end{array}$ & $\begin{array}{l}\stackrel{y}{3} \\
\frac{y}{5} \\
\vdots\end{array}$ & 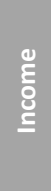 & $\frac{\text { 플 }}{\frac{10}{10}}$ & $\begin{array}{l}\text { 들 } \\
\text { 융 } \\
\text { 뀸 }\end{array}$ & $\begin{array}{l}\text { 를 } \\
\text { हू } \\
\text { 을 } \\
\text { 두 }\end{array}$ & 常 & 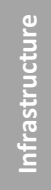 & 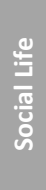 & 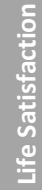 \\
\hline Sakarya & 2 & 1 & 28 & 33 & 14 & 38 & 14 & 26 & 20 & 6 & 15 \\
\hline İstanbul & 5 & 28 & 33 & 1 & 29 & 56 & 37 & 73 & 1 & 1 & 50 \\
\hline Balıkesir & 7 & 27 & 24 & 36 & 33 & 12 & 9 & 35 & 12 & 14 & 11 \\
\hline Rize & 14 & 7 & 5 & 27 & 3 & 27 & 11 & 5 & 36 & 48 & 34 \\
\hline Ankara & 17 & 8 & 37 & 2 & 6 & 44 & 59 & 75 & 3 & 4 & 64 \\
\hline Bursa & 19 & 35 & 12 & 18 & 35 & 29 & 48 & 43 & 6 & 10 & 35 \\
\hline Trabzon & 20 & 36 & 56 & 20 & 4 & 19 & 29 & 23 & 11 & 12 & 55 \\
\hline İzmir & 21 & 18 & 60 & 3 & 16 & 31 & 36 & 66 & 2 & 22 & 51 \\
\hline Çankırı & 22 & 10 & 54 & 28 & 34 & 45 & 35 & 11 & 59 & 42 & 6 \\
\hline Kocaeli & 23 & 32 & 10 & 4 & 48 & 39 & 30 & 70 & 10 & 33 & 57 \\
\hline Giresun & 29 & 13 & 46 & 48 & 15 & 7 & 45 & 9 & 48 & 28 & 22 \\
\hline Tekirdağ & 30 & 22 & 6 & 5 & 53 & 46 & 24 & 55 & 17 & 20 & 61 \\
\hline Samsun & 33 & 31 & 41 & 40 & 18 & 22 & 38 & 40 & 30 & 29 & 37 \\
\hline Kastamonu & 36 & 16 & 44 & 38 & 46 & 37 & 1 & 39 & 55 & 40 & 43 \\
\hline Tokat & 39 & 40 & 34 & 51 & 44 & 21 & 31 & 24 & 47 & 34 & 47 \\
\hline Sivas & 40 & 43 & 53 & 29 & 28 & 55 & 34 & 18 & 41 & 62 & 45 \\
\hline Antalya & 44 & 23 & 29 & 8 & 41 & 16 & 21 & 79 & 9 & 46 & 78 \\
\hline Muğla & 45 & 44 & 23 & 15 & 12 & 26 & 16 & 81 & 22 & 30 & 72 \\
\hline Ordu & 55 & 46 & 50 & 56 & 32 & 49 & 43 & 25 & 61 & 69 & 52 \\
\hline
\end{tabular}

Source: Table generated using TurkStat data.

\section{Discussion}

This article addresses the pattern of lifestyle migration in Turkey. The findings are based on the secondary data in order to evaluate the individuals' preferences of urban life by migrating to the smaller cities. Data reveals that people are trying to improve the quality of life in their lives. Lifestyle migration is mainly studied in the literature through foreign migration, but it is observed that the domestic migration pattern in Turkey takes place to improve the quality of life. In this context, the province that receives the migration from İstanbul is very important. As seen in Table 5, most people migrate to smaller cities. This shows that Turkish people migrate with an aim of improving their quality of life. There are many factors that change people's living preferences and strategies such as intense, crowded and stressful life in metropolitan cities. Social changes, in the city, indicate that individuals make decisions based on these changes and lifestyle migration, which is an indicator of the dialectic of the structure-agency, also appears as part of such a change.

The fact that İstanbul has a net out-migration since 2015, such a trend can be related to the change of living conditions in the city. This relation brings new lifestyle preferences, lifestyle migration (Benson, 2010; O'Reilly \& Benson, 2009) and new urban life trends up for discussion. According to the 2015 well-being index data, most of the provinces, which received migration from İstanbul, have higher scores than İstanbul in different value categories. In the context of the literature on lifestyle migration, individuals' desires to try to live their lives in a good way can be considered as a reason for the increasing migration rate from İstanbul to other cities. Thus, the descriptive statistics have been discussed in the following depending on the living, economic and environmental conditions and time management of İstanbul. 
The decreasing attractiveness of urban living and the desire of individuals to change their living circumstances in the city increase the motivation of migration; thus the action that Tuan (2015) calls escape moves towards a better life is called lifestyle migration by O'Reilly and Benson (2009). Today, the profile of İstanbul, within the scope of the quality of life, is seen in the studies conducted with different criteria. The first study to be mentioned in this context is about stressful life. According to the study of Zipjet (2017), Istanbul is ranked as the $30^{\text {th }}$ most stressful city among 150 ranked cities. This study has ranked the world's most stressful cities using factors such as traffic, security, employment, mental-physical health, transportation and the amount of sunshine hours to determine the stress levels of residents of the world's largest cities. At this point, the provinces, which receive migration from İstanbul, have less population density, a simpler and stress-free life as compared to İstanbul. As Simmel (1969) indicates that the effects of the chaotic environment appear in individuals' daily lives. It can be specified that people do not want stress or rat race in their lives, and they try to change this by migrating to other less stressful cities. The desire to live a less stressful life is thus can be viewed as the main motivation of Turkish people to migrate from Istanbul to the country's other provinces.

In addition, one can say that migration from İstanbul to other cities and provinces, is efficient in terms of time management. As Giddens (1991) states that holding a dialogue with time provides to individuals for spending more time for themselves in everyday life. The population density in large-scale cities increases the physical distance in the city and causes individuals to travel between home and work for minutes and even hours. According to the global traffic scorecard (2018), İstanbul is ranked as the second city, which has intense traffic. The Inrix Global Traffic Scorecard is an analysis of congestion and mobility trends in 220 cities. According to the research report of another study about traffic, Automobile Rhythms of İstanbul (2019), the distance to be traveled in 10 minutes in open traffic was taken in about 55 minutes. Every person spends 1 hour and 10 minutes because of traffic congestion. This means that those living in İstanbul spend 4 years of their lives in traffic. The increase in the amount of time spent in traffic causes not only quality time loss but also environmental pollution and mental fatigue of people. It is possible to say that traffic is also one of the examples of the intense and compressed life that Simmel (1969) mentions as the reason of mental fatigue for individuals in the city. All of these factors negatively affect the people's ability of self-realization and their capacity to spend productive time. Thus migrants from İstanbul tend to choose a better urban life for self-realization (O’Reilly \& Benson, 2009).

Finally, İstanbul does not have a good ranking in the green area statistics. According to the Global Power City Index (2017), İstanbul is ranked low as the 40th greenest city in 44 cities, and this affects the quality of air in the city. Most of the provinces, which receive migration from İstanbul, are located in the Black Sea Region, and this case is closely related to the intense migration from this region in the 1950s, as well as the characteristics of this region. In the context of the environment and living conditions, the Black Sea Region includes provinces with greener areas and cleaner air. It can be said that geography has a meaning for self-realization, lifestyle and personal renewal, and includes personal experiences and representations. Another point to be considered here is the tendency towards a simple and nature-oriented life. The claim to nature and the desire to enjoy it reflect a tendency to flee the deteriorated city, alienated urban life (Lefebvre, 1996: 158). Hence, urban lifestyle exhausts the individual mentally and it reduces the people's chances to experience a simple and less stressful life. People generally perceive simple life positively because of the negativities in the urban life. With regard to contemporary migration patterns, the action we call lifestyle migration from the metropolis symbolizes the escape from the negative features of the city. Escape from urban life has many direct and indirect motivations. According to Lefebvre (1996: 157-8), the perception that people have a right to access to nature emerged in response to because the noise, fatigue in the concentrationary universe of the explosion of urbanization (expansion of the city wall and suburbanization). Thus, the metropolis, which erodes the individuals' lives, paves the way for a different consumption with the changes that it 
creates. The important parts of this consumption are therapeutic place, idyll, ecological and organic culture. In urban life, where a fluid life prevails, the individual starts to turn towards nature and the natural one, which brings us to the consumption of the ecological as a new consumption culture. Thus, the individual who consumes the city today increasingly wants access to consume the countryside in the future. All of them indicate that consumer society is becoming a way of life and the goal is always to live better, produce more and consume more (Marcuse, 2006: 14). The metropolis without natural areas drives residents to nature, and thereby makes the countryside an object of consumption. In other words, we can assert that the artificial nature life in the metropolis leads the individual to the consumption of the rural/nature, and the process of the escape from the metropolis takes place in the context of the object of consumption. From this angle, smaller-scale cities and its lifestyle will gain more importance in the future because of the simple, stress-free life and the integration of rural and urban areas.

\section{Conclusion}

Lifestyle migration, which reflects a new migration tendency, is depicted with a new lifestyle and a good way of life. As urban life becomes more chaotic, interest in the lowest population density areas, rural areas and areas with close contact with rural areas lead to population mobility. It can be mentioned that the lifestyle migration associated with the life troubles in the city and the problems in individuals' lives have created new mobility pattern, new practices and producing a different urban life. Because as the statistics in Turkey have shown that people escape to smaller places from major metropolitan areas and in small place is easier to live socially than metropolitan areas. Many reasons -such as disappointment of individuals, decrease in the quality of life, increase in security problems and disruption of the time management because of the life in the metropolis- support the migration motivations of individuals. The current conditions and changes in large-scale cities lead individuals to consider different life strategies. In this sense, the process of modernization and the development of technology create new sort of mobility, the possibility of different life and the significant changes in the population dynamics in cities.

As it was seen in İstanbul, migration data in the last three years, gives us clues about new migration patterns in the country because İstanbul has always been a migrant-receiving place but has been more migrant-giving place in the past three years. The fact that İstanbul does not give good results in evaluations made according to traffic, quality of life, stressful life, and environmental conditions causes the change in the hard situations in the city by metropolitan residents. The business life has an important place in human's time zone and in İstanbul, going to work and turning back to the home of an individual is double or even triple the normal time due to traffic. This situation makes individuals' lives more stressful, less productive, physically and mentally tiring. The truth is that metropolis loses its dialogue with time, causes deterioration of environmental conditions and decreases in quality of life. In this context, the social and economic transformations in the city trigger the population to prefer to live in relatively smaller cities and aim to enhance their lives. These cities, which include a simpler urban life and provide a good life, are those where the population density is low, the environmental conditions are better, the individual can hold a dialogue with time, and s/he can realize him/herself. Social transformation changes to migration patterns and reveals the different trends in urban life in the context of Turkey; in this regard, the characteristics of these cities gain importance as an indicator of social change. Consequently, it can be said that this paper has shown that the natural/ecological living conditions in the migrant-receiving locations from İstanbul will be the models of urban life and urbanization, which includes active rural-urban area will be more important in the future. 


\section{Acknowledgements}

This research did not receive any specific grant from funding agencies in the public commercial, or not-for-profit sectors.

The author declares no competing interests.

\section{References}

Ær $\oslash$, T. (2006). Residential choice from a lifestyle perspective. Housing, Theory and Society, 23(2), 109130. https://doi.org/10.1080/14036090600773139

Aner, L. (2016). Dwelling habitus and urban out-migration in Denmark. European Urban and Regional Studies, 23(4), 662-676. https://doi.org/10.1177/0969776414532932

Bauman, Z. (2008). The art of life. Cambridge: Polity Press.

Benson, M. (2010). The context and trajectory of lifestyle migration. European Societies, 12(1), 45-64. https://doi.org/10.1080/14616690802592605

Benson, M., \& O'Reilly, K. (2009). Migration and the search for a better way of life: a critical exploration of lifestyle migration. The Sociological Review, 57(4), 608-625. https://doi.org/10.1111/j.1467954X.2009.01864.X

Clark, W. A. V., \& Onaka, Jun L. (1983). Life cycle and housing adjustment as explanations of residential mobility. Urban Studies, 2O(1), 47-57. https://doi.org/10.1080/00420988320080041

Clark, W. A. V., Deurloo, M. C., \& Dieleman, M. F. (1984). Housing consumption and residential mobility. Annals of the Association of American Geographers, 74(1), 29-43. https://doi.org/10.1111/j.1467-8306.1984.tbo1432.x

Eimermann, M. (2013). Lifestyle migration to the north: Dutch families and the decision to move to rural Sweden. Population, Space and Place, 21(1), 68-85. https://doi.org/10.1002/psp.1807

Giddens, A. (1986). The constitution of society. California: University of California Press.

Giddens, A. (1991). Modernity and self-identity: Self and society in the late modern age. Cambridge: Polity Press.

Gkartzios, M., \& Scott, K. (2015). A cultural panic in the province? Counterurbanization mobilities, creativity, and crisis in Greece. Population, Space and Place, 21(8), 843-855. https://doi.org/10.1002/psp.1933

Goffman, E. (1956). The presentation of self in everyday life. Edinburgh: University of Edinburgh.

Heaton, J. (2008). Secondary analysis of qualitative data: An overview. Historical Social Research, 33(3), 33-45. https://doi.org/10.12759/hsr.33.2008.3.33-45

Hoey, B. (2010). Place for personhood: Individual and local character in lifestyle migration. City \& Society, 22(2), 237-261. https://doi.org/10.1111/j.1548-744X.2010.01041.X

Huete, R., Mantecón, A., \& Estévez, J. (2013). Challenges in lifestyle migration research: Reflections and findings about the Spanish crisis. Mobilities, 8(3), 331-348. https://doi.org/10.1080/17450101.2013.814236

Lefebvre, H. (1996). Writings on cities. Massachusetts: Wiley-Blackwell.

Marcuse, H. (2006). One-dimensional man. London: Routledge. 
Nefedova, T. G., Pokrovskii, N. E., \& Treivish, A. I. (2016). Urbanization, counter-urbanization, and ruralurban communities facing growing horizontal mobility. Sociological Research, 55(3), 195-210. https://doi.org/10.1080/10610154.2016.1245570

O'Reilly, K., \& Benson, M. (2009). Lifestyle migration: Escaping to the good life? In M. Benson \& K. O'Reilly (Eds.), Lifestyle migrations: Expectations, aspirations and experiences (pp.1-13). Surrey: Ashgate Publishing.

Robins, D. (2019). Lifestyle migration from the Global South to the Global North: Individualism, social class, and freedom in a centre of "superdiversity". Population, Space and Place, 25(6), 22-36. https://doi.org/10.1002/psp.628

Simmel, G. (1969). The metropolis and mental life. In R. Sennett (Eds.), Classic essay on the culture of the city (pp. 47-60). New York: Appleton-Century-Crofts.

Şatıroğlu, A. (2014). Ayda Yörükân'ın kent sosyolojisi çalışmaları [Ayda Yörükân's Works on Urban Sociology]. Sosyoloji Dergisi, 29(3), 387-402. https://doi.org/10.16917/sd.16402

Tekeli, İ. (2007). Türkiye'nin göç tarihindeki değişik kategoriler [Different categories of Turkey's immigration history]. In A. Kaya \& B. Şahin (Eds.), Kökler ve yollar: Türkiye'de göç süreçleri (pp. 447-474). İstanbul: Bilgi Üniversitesi Yayınları.

Torkington, K. (2012). Place and lifestyle migration: The discursive construction of "glocal" place-identity. Mobilities, 7(1), 71-92. https://doi.org/10.1080/17450101.2012.631812

Tuan, Y. (2015). Bir kurucu unsur olarak kaçış [Escapism]. İstanbul: Litera Yayıncılık. 